Maria Hudakova - Jan Dvorsky

\title{
ANALVSIS OF THE MARKET RISK SOURCES IN THE SMALL AND MEDIUM-SIZED ENTERPRISES OF TRANSPORT
}

The aim of this paper was to define the important market risk sources in the transport small and medium-sized enterprises segment. A part of this aim is to find out how entrepreneurs evaluate these sources, and quantify the differences in their evaluation based on the entrepreneur's characteristics, such as nationality, age, gender and others. The questionnaire was completed by 122 enterprises from Slovakia, Poland, the Czech Republic and Serbia. Statistical tools such as pivot tables, percentages and goodness-of-fit tests were applied to verify the formulated hypotheses. The most important source of market risk is a strong competition in the line of business. The obtained education of entrepreneurs is statistically significant characteristics for the evaluation of the market risk sources in selected transport enterprises. The findings are important for state institutions and their support systems in the transport SMEs segment.

Keywords: market risk, small and medium-sized enterprise, transport, losing the customers, stagnation of the market

\section{Introduction}

Enterprises are facing constant changes in the business environment and the way to deal with these changes also depends on the ability of the enterprise to adapt and accept the variability of everyday life [1]. The issues of market risk management in small and medium-sized enterprises (SMEs) have been analyzed and discussed for a long time [2]. The enterprise (also transport enterprise), is facing constant changes in the business environment at the national level and the way to deal with these changes also depends on the ability of the enterprise to adapt and accept the new actualities [3-4].

The paper contains a detailed analysis of the following market risk sources: losing the customers; a strong competition in the line of business; stagnation of the market; unreliability of the suppliers. The case study presents the answers from 122 transport enterprises in Slovakia, the Czech Republic, Poland and Serbia.

The structure of the paper is as follows: The first part presents current findings in the small and medium-sized enterprises of the transport segment. The second part defines the aim of the paper, the research methodology, research methods and the data collection. The section of Results presents the evaluation of the empirical research of market risk sources. In the discussion, there is a comparison to other research results presented. The conclusion offers a final summary of own research, its limits and future.

\section{Short literature background}

The risk management is a global process and a driver for business process innovation. Its deployment needs to be supported by a knowledge base associated with a decision support system [5]. In both developed and emerging economies, capital markets have become more important as a means of allocating resources. As a result, both banks and non-financial firms have realized that the number, type and extent of their exposures have increased significantly. Finally, a spate of volatile financial innovations are simultaneously a source of risk and a means to mitigate it [6].

To an economist, risk is defined as the existence of uncertainty about future outcomes [7]. Risk is a key factor in economic life because people and firms make irrevocable investments in research and product development, plant and equipment, inventory and human capital, without knowing whether the future cash flows from these investments will be sufficient to compensate both debt and equity holders [8-9].

Global surveys show that even though the risk management of the company is not a new discipline, current models of risk management are not flexible enough to be able to take into account the dynamics of the market [10].

According to Dvorsky et al. and Costa and Fernandes [11-12], the market risk related sources that exert the most negative influence on enterprise success are an increased competition, limited market size, low demand, inefficient marketing, poor understanding of competitors, poor

\footnotetext{
Maria Hudakova ${ }^{1}$, Jan Dvorsky ${ }^{2, *}$

${ }^{1}$ Department of Crisis Management, Faculty of Security Engineering, University of Zilina, Slovakia

${ }^{2}$ Department of Business Administration, Faculty of Management and Economics, Tomas Bata University in Zlin, Czech Republic

*E-mail of corresponding author: j1dvorsky@utb.cz
} 
understanding of location and markets and the inability to identify the target market [13-14].

The authors in general think that to successfully manage or control any transport activity, it is necessary to determine the degree and extent of risk. They define the terms "risk", "risk management" and other relevant concepts in this field as being that risk management is one of the modern working methods that are important not only for transport companies but also for other organizations and other companies. The outcome of their research analysis is the essential risk reduction according to implementation of the Lean System and adaptation of the Outsourcing system with a transport company. Those methods are important for the risk analysis in a transport company [15-16].

\section{Data, methodology and methods}

The aim of the paper is to define important market risk sources in the transport SME segment and to find out how entrepreneurs evaluate these sources and quantify the differences in their evaluation based on the entrepreneur's characteristics (nationality, age, gender, obtained education and how long the entrepreneurs have been doing business) and the enterprises' number of employees.

The data collection was carried out in 2017 and 2018. The sample consisted of 1,689 enterprises in Slovakia, the Czech Republic, Poland and Serbia. The structure of the sample represents small and medium-sized enterprises in the four countries studied. The data was collected through a standard questionnaire via an online survey. The answers given by the respondents were recorded online in the four countries by means of questionnaire. With regard to the content and form of the questionnaire used during the survey, great attempts were made to ensure that the questions were comprehensible and to completely filter out any ambiguity, even in terms of the order of the questions.

The entrepreneurs were selected using 'the random selection method' (using the 'Randbetween' function) from specialized databases of entrepreneurs for each country (Slovakia - Cribis database, Czech Republic - Albertina database, Poland - Central Registration and Information on Business (CEIDG), Serbia - Statistical Office of the Republic of Serbia (OP3C)). With this method, randomness was ensured. Of the 1,689 small and medium-sized enterprises analyzed, Slovakia provided 487 respondents (28.8\%), Poland 474 (28.1\%), the Czech Republic 408 (24.2\%) and Serbia 320 (18.9\%).

The entrepreneurs could give their opinion to the risk sources, which affect the enterprise intensively - a very low intensity of the risk source (A1); a low intensity of the risk source (A2); a medium intensity of the risk source (A3); a high intensity of the risk source (A4) and a very high intensity of the risk source (A5). The explanation: the attitudes of entrepreneurs are: low intensity (A1+A2); medium intensity (A3) and high intensity (A4+A5) (three point Likert scale in Tables 1-6).
The authors used questionnaire who contained sources for the market risk, economic, financial, operational, personnel, security and legal risks. Each risk was created from four sources of risk (the sources of risk were created by authors). The sources of the market risk (MR): losing the customers (MR1); strong competition in the line of business (MR2); stagnation of the market (MR3); unreliability of the suppliers (MR4). The following hypotheses were made in order to achieve the main aim of the study:

$\mathrm{H}$ : Within the defined (H1: nationality; H2: gender; H3: age; H4: obtained education; H5: number of employees and H6: how long the entrepreneurs have been doing business) groups of entrepreneurs, there are statistically significant differences in the evaluation of market risk sources.

To evaluate the formulated hypotheses and thus meet the primary goal of the paper, the tools of descriptive statistics such as tables and descriptive characteristics (frequency, percentages, sum). Then, the relationship between qualitative answers of entrepreneurs (using Pivot Table) and contingency intensity was used (using the Pearson's coefficient of contingency, which is based on the Chi-square). The Pearson's coefficient was calculated and then interpreted because of the decision about the statistical significance of differences between selected groups of the entrepreneurs. For assessment of the level of significance (limit of acceptance or rejection of hypothesis) the level of $p$-value 0.05 was used. Calculations were made using the analytical software SPSS Statistics.

The transport entrepreneurs were chosen based on demographic characteristics (gender, age, education, nationality) and the companies based on selected criteria (number of employees, how many years they have been doing business). The structure of the transport entrepreneurs' characteristics who filled in the questionnaire was as follows: the nationality: Slovak entrepreneurs - 31 (25.4\%); Czech entrepreneurs - 20 (16.4\%); Polish entrepreneurs - 51 (41.8\%) and Serbian entrepreneurs - 20 (16.4\%); the gender: male - 96 (79\%); female - 26 (21\%); the age - up to 30 years - 38 (31.2\%); from 31 to 50 years - 62 (50.8 \%); over 50 years - 22 (18.0\%); the obtained education - secondary school without the school-leaving exam - 19 (15.6\%); secondary school with the school-leaving exam - 58 (47.5\%); university graduates - 45 (36.9\%). The selected characteristics of the companies: the number of employees - micro-enterprises (to 10 employees) - 69 (56.6\%); a small company (to 50 employees) - 43 (35.2 \%); a medium-sized company (to 250 employees) - 10 ( $8.2 \%$ ); how long the entrepreneurs have been doing business: more than 10 years - 53 (43.4\%), from 5 to 10 years - 32 (26.2\%), from 1 to 5 years - 37 (30.3\%).

\section{Results and discussion}

The following Tables 1-6 summarise the results of the assessment of the market risk' sources (MR1, MR2, MR3, MR4) of entrepreneurs according to the selected characteristics. The structure of the market risk' sources according to transport entrepreneurs was $(n=122)$ : MR1 
Table 1 The evaluation of sources of market risk according to nationality

\begin{tabular}{|c|c|c|c|c|c|c|c|c|c|}
\hline MR1 & SR & PL & $\mathrm{CR}$ & SRB & MR2 & SR & $\mathrm{PL}$ & $\mathrm{CR}$ & SRB \\
\hline Low intensity: & 8 & 9 & 5 & 5 & Low intensity: & 6 & 5 & 5 & 5 \\
\hline $19.7 \%$ & $26 \%$ & $18 \%$ & $25 \%$ & $25 \%$ & $11.5 \%$ & $19 \%$ & $10 \%$ & $25 \%$ & $25 \%$ \\
\hline Medium intensity: & 11 & 14 & 6 & 5 & Medium intensity: & 8 & 14 & 8 & 5 \\
\hline $26.2 \%$ & $35 \%$ & $27 \%$ & $30 \%$ & $25 \%$ & $29.5 \%$ & $26 \%$ & $27 \%$ & $40 \%$ & $25 \%$ \\
\hline High intensity: & 12 & 28 & 9 & 10 & High intensity: & 17 & 32 & 7 & 10 \\
\hline $54.1 \%$ & $39 \%$ & $55 \%$ & $45 \%$ & $50 \%$ & $59.0 \%$ & $55 \%$ & $63 \%$ & $35 \%$ & $50 \%$ \\
\hline MR3 & SR & PL & $\mathrm{CR}$ & SRB & MR4 & SR & $\mathrm{PL}$ & $\mathrm{CR}$ & SRB \\
\hline Low intensity: & 7 & 11 & 8 & 6 & Low intensity: & 15 & 13 & 8 & 9 \\
\hline $26.2 \%$ & $23 \%$ & $22 \%$ & $40 \%$ & $30 \%$ & $37.7 \%$ & $48 \%$ & $25 \%$ & $40 \%$ & $45 \%$ \\
\hline Medium intensity: & 19 & 23 & 7 & 7 & Medium intensity: & 9 & 20 & 7 & 5 \\
\hline $45.9 \%$ & $61 \%$ & $45 \%$ & $35 \%$ & $35 \%$ & $33.6 \%$ & $29 \%$ & $39 \%$ & $35 \%$ & $25 \%$ \\
\hline High intensity: & 5 & 17 & 5 & 7 & High intensity: & 7 & 18 & 5 & 6 \\
\hline $27.9 \%$ & $16 \%$ & $33 \%$ & $25 \%$ & $35 \%$ & $28.7 \%$ & $23 \%$ & $35 \%$ & $25 \%$ & $30 \%$ \\
\hline
\end{tabular}

Note: SR - Slovakia; PL - Poland; SRB - Serbia, CR - Czech Republic. Source: own data collection.

Table 2 The evaluation of sources of market risk according to gender of entrepreneurs

\begin{tabular}{|c|c|c|c|c|c|}
\hline MR1 & Male & Female & MR2 & Male & Female \\
\hline Low intensity: & 21 & 5 & Low intensity: & 12 & 5 \\
\hline $19.7 \%$ & $22 \%$ & $19 \%$ & $11.5 \%$ & $13 \%$ & $19 \%$ \\
\hline Medium intensity: & 31 & 5 & Medium intensity: & 32 & 6 \\
\hline $26.2 \%$ & $32 \%$ & $19 \%$ & $29.5 \%$ & $33 \%$ & $23 \%$ \\
\hline High intensity: & 44 & 16 & High intensity: & 52 & 15 \\
\hline $54.1 \%$ & $46 \%$ & $62 \%$ & $59.0 \%$ & $54 \%$ & $58 \%$ \\
\hline MR3 & Male & Female & MR4 & Male & Female \\
\hline Low intensity: & 25 & 7 & Low intensity: & 36 & 10 \\
\hline $26.2 \%$ & $26 \%$ & $27 \%$ & $37.7 \%$ & $38 \%$ & $38 \%$ \\
\hline Medium intensity: & 45 & 11 & Medium intensity: & 34 & 7 \\
\hline $45.9 \%$ & $47 \%$ & $42 \%$ & $33.6 \%$ & $35 \%$ & $27 \%$ \\
\hline High intensity: & 26 & 8 & High intensity: & 26 & 9 \\
\hline $27.9 \%$ & $27 \%$ & $31 \%$ & $28.7 \%$ & $27 \%$ & $35 \%$ \\
\hline
\end{tabular}

Source: own data collection.

- low intensity (A1+A2) 24 (19.7\%); medium intensity (A3) 32 (26.2\%); high intensity (A4+A5) 66 (54.1\%); MR2 - low intensity (A1+A2) 14 (11.5\%); medium intensity (A3) 36 (29.5 \%); high intensity (A4+A5) 72 (59.0\%); MR3 - low intensity (A1+A2) 32 (26.2\%); medium intensity (A3) 56 (45.9\%); high intensity (A4+A5) 34 (27.9\%); MR4 - low intensity (A1+A2) 46 (37.7 \%); medium intensity (A3) 41 (33.6 \%); high intensity (A4+A5) 35 (28.7\%).

The nationality of entrepreneurs is not a statistically significant characteristics of evaluating the market source: losing the customers ( $p$ - value $=0.324)$; strong competition in the line of business ( $p$ - value $=0.118$ ); stagnation of the market ( $p$ - value $=0.295)$; unreliability of the suppliers ( $p$ value $=0.217$ ). Hypothesis H1 is rejected.

The gender of entrepreneurs is not a statistically significant characteristics of evaluating the market source: "losing the customers" ( $p$ - value $=0.718)$; strong competition in the line of business ( $p$ - value $=0.108$ ); stagnation of the market $(p-$ value $=0.905)$; unreliability of the suppliers $(p$ value $=0.144)$. Hypothesis $\mathrm{H} 2$ is rejected.

The age of entrepreneurs is not a statistically significant characteristics of evaluating the market source: "losing the customers" ( $p$ - value $=0.238)$; strong competition in the line of business $(p$ - value $=0.314)$; stagnation of the market $(p-$ value $=0.148)$; unreliability of the suppliers $(p-$ value $=$ 0.273). Hypothesis $\mathrm{H} 3$ is rejected.

The obtained education of entrepreneurs is a statistically significant characteristics of evaluating the market source: "losing the customers" ( $p$ - value $=0.045$ ); strong competition in the line of business ( $p$ - value $=0.004$ ); stagnation of the market $(p-$ value $=0.047)$; unreliability of the suppliers $(p-$ value $=0.033)$. Hypothesis H4 is accepted. 
Table 3 The evaluation of sources of market risk according to age of entrepreneurs

\begin{tabular}{|c|c|c|c|c|c|c|c|}
\hline MR1 & $>30$ & $30-50$ & $50<$ & MR2 & $>30$ & $30-50$ & $50<$ \\
\hline Low intensity: & 7 & 14 & 5 & Low intensity: & 6 & 5 & 5 \\
\hline $19.7 \%$ & $18 \%$ & $23 \%$ & $23 \%$ & $11.5 \%$ & $16 \%$ & $8 \%$ & $23 \%$ \\
\hline Medium intensity: & 8 & 14 & 10 & Medium intensity: & 8 & 21 & 6 \\
\hline $26.2 \%$ & $21 \%$ & $23 \%$ & $45 \%$ & $29.5 \%$ & $21 \%$ & $34 \%$ & $27 \%$ \\
\hline High intensity: & 23 & 34 & 7 & High intensity: & 24 & 36 & 11 \\
\hline $54.1 \%$ & $61 \%$ & $55 \%$ & $32 \%$ & $59.0 \%$ & $63 \%$ & $58 \%$ & $50 \%$ \\
\hline MR3 & $>30$ & $30-50$ & $50<$ & MR4 & $>30$ & $30-50$ & $50<$ \\
\hline Low intensity: & 8 & 18 & 6 & Low intensity: & 11 & 27 & 8 \\
\hline $26.2 \%$ & $21 \%$ & $29 \%$ & $27 \%$ & $37.7 \%$ & $29 \%$ & $44 \%$ & $36 \%$ \\
\hline Medium intensity: & 15 & 33 & 8 & Medium intensity: & 14 & 22 & 5 \\
\hline $45.9 \%$ & $39 \%$ & $53 \%$ & $36 \%$ & $33.6 \%$ & $37 \%$ & $35 \%$ & $23 \%$ \\
\hline High intensity: & 15 & 11 & 8 & High intensity: & 13 & 13 & 9 \\
\hline $27.9 \%$ & $39 \%$ & $18 \%$ & $36 \%$ & $28.7 \%$ & $34 \%$ & $21 \%$ & $41 \%$ \\
\hline
\end{tabular}

Note: The age up to 30 years ( $>30)$; the age from 31 to 50 years (30-50); the age over 50 years $(50<)$. Source: own data collection.

Table 4 The evaluation of sources of market risk according to obtained education of entrepreneurs

\begin{tabular}{cccccccc}
\hline MR1 & SS & SSw & UG & MR2 & SS & SSw & UG \\
\hline Low intensity: & 5 & 14 & 5 & Low intensity: & 5 & 5 & 8 \\
19.7\% & $26 \%$ & $24 \%$ & $11 \%$ & $11.5 \%$ & $26 \%$ & $9 \%$ & $18 \%$ \\
Medium intensity: & 6 & 18 & 8 & Medium intensity: & 7 & 20 & 6 \\
$26.2 \%$ & $32 \%$ & $31 \%$ & $18 \%$ & $29.5 \%$ & $37 \%$ & $34 \%$ & $13 \%$ \\
High intensity: & 8 & 26 & 32 & High intensity: & 7 & 33 & 31 \\
$54.1 \%$ & $42 \%$ & $45 \%$ & $71 \%$ & $59.0 \%$ & $37 \%$ & $57 \%$ & $69 \%$ \\
\hline MR3 & SS & SSw & UG & MR4 & SS & SSw & UG \\
\hline Low intensity: & 5 & 13 & 15 & Low intensity: & 6 & 22 & 17 \\
26.2\% & $26 \%$ & $22 \%$ & $33 \%$ & $37.7 \%$ & $32 \%$ & $38 \%$ & $38 \%$ \\
Medium intensity: & 9 & 32 & 13 & Medium intensity: & 8 & 15 & 15 \\
45.9\% & $47 \%$ & $55 \%$ & $29 \%$ & $33.6 \%$ & $42 \%$ & $26 \%$ & $33 \%$ \\
High intensity: & 5 & 13 & 17 & High intensity: & 5 & 21 & 13 \\
$27.9 \%$ & $26 \%$ & $22 \%$ & $38 \%$ & $28.7 \%$ & $26 \%$ & $36 \%$ & $29 \%$ \\
\hline
\end{tabular}

Note: The obtained education - secondary school without the school-leaving exam (SS); secondary school with the school-leaving exam (SSw) and university graduates (UG). Source: own data collection.

The number of employees of enterprises is not a statistically significant characteristics of evaluating the market source: strong competition in the line of business ( $p$ - value $=0.914) ;$ stagnation of the market $(p-$ value $=0.946)$; unreliability of the suppliers $(p$ - value $=0.575)$. The number of employees of enterprises is the statistical significant of evaluating the market source: "losing the customers" ( $p$ value $=0.042$ ). Hypothesis H5 is rejected.

The age of enterprises is not a statistically significant characteristics of evaluating the market source: "losing the customers" $(p-$ value $=0.612)$; strong competition in the line of business ( $p$ - value $=0.984)$; stagnation of the market $(p-$ value $=0.748)$; unreliability of the suppliers $(p-$ value $=$ 0.186). Hypothesis H6 is rejected.

The most important source of market risk is "a strong competition in the line of business" (59\% of all entrepreneurs). The second most important source of market risk is "losing the customers" (54.1\% of all entrepreneurs). Then, it is sources "unreliability of the suppliers" (28.7\% of all entrepreneurs) and "stagnation of the market" ( $27.9 \%$ of all entrepreneurs).

Own research results show that within the defined obtained education groups of the entrepreneurs, there are significant differences in the evaluation of the market risk sources ( $p$-value of Chi-square tests are lower than the level of significance).

The biggest barriers that prevent the transport enterprises from an effective control of the market risks relate to the problems regarding the availability of information, no matter if internal or external data. Such information is necessary for evaluation and risk management, or their integration into the decision 
Table 5 The evaluation of sources of market risk according to number of employees

\begin{tabular}{|c|c|c|c|c|c|}
\hline MR1 & MIE & $\mathrm{SE}+\mathrm{ME}$ & MR2 & MIE & $\mathrm{SE}+\mathrm{ME}$ \\
\hline Low intensity: & 17 & 7 & Low intensity: & 9 & 5 \\
\hline $19.7 \%$ & $25 \%$ & $13 \%$ & $11.5 \%$ & $13 \%$ & $9 \%$ \\
\hline Medium intensity: & 23 & 9 & Medium intensity: & 21 & 15 \\
\hline $26.2 \%$ & $33 \%$ & $17 \%$ & $29.5 \%$ & $30 \%$ & $28 \%$ \\
\hline High intensity: & 29 & 37 & High intensity: & 39 & 33 \\
\hline $54.1 \%$ & $42 \%$ & $70 \%$ & $59.0 \%$ & $57 \%$ & $62 \%$ \\
\hline MR3 & MIE & $\mathrm{SE}$ & MR4 & MIE & $\mathrm{SE}$ \\
\hline Low intensity: & 17 & 15 & Low intensity: & 29 & 17 \\
\hline $26.2 \%$ & $25 \%$ & $28 \%$ & $37.7 \%$ & $42 \%$ & $32 \%$ \\
\hline Medium intensity: & 33 & 23 & Medium intensity: & 24 & 17 \\
\hline $45.9 \%$ & $48 \%$ & $43 \%$ & $33.6 \%$ & $35 \%$ & $32 \%$ \\
\hline High intensity: & 19 & 15 & High intensity: & 16 & 19 \\
\hline $27.9 \%$ & $28 \%$ & $28 \%$ & $28.7 \%$ & $23 \%$ & $36 \%$ \\
\hline
\end{tabular}

Note: MIE - micro-enterprise (to 10 employees); SE - small enterprise (to 50 employees); ME - medium enterprise (to 250 employees). Source: own data collection.

Table 6 The evaluation of sources of market risk according to how long the entrepreneurs have been doing business

\begin{tabular}{|c|c|c|c|c|c|c|c|}
\hline MR1 & $1-5$ & $5-10$ & $10+$ & MR2 & $1-5$ & $5-10$ & $10_{+}$ \\
\hline Low intensity: & 10 & 5 & 9 & Low intensity: & 5 & 5 & 6 \\
\hline $19.7 \%$ & $27 \%$ & $16 \%$ & $17 \%$ & $11.5 \%$ & $14 \%$ & $16 \%$ & $11 \%$ \\
\hline Medium intensity: & 10 & 7 & 15 & Medium intensity: & 10 & 10 & 16 \\
\hline $26.2 \%$ & $27 \%$ & $22 \%$ & $28 \%$ & $29.5 \%$ & $27 \%$ & $31 \%$ & $30 \%$ \\
\hline High intensity: & 17 & 20 & 29 & High intensity: & 22 & 17 & 31 \\
\hline $54.1 \%$ & $46 \%$ & $63 \%$ & $55 \%$ & $59.0 \%$ & $59 \%$ & $53 \%$ & $58 \%$ \\
\hline MR3 & $1-5$ & $5-10$ & $10+$ & MR4 & $1-5$ & $5-10$ & $10+$ \\
\hline Low intensity: & 8 & 11 & 13 & Low intensity: & 15 & 7 & 24 \\
\hline $26.2 \%$ & $22 \%$ & $34 \%$ & $25 \%$ & $37.7 \%$ & $41 \%$ & $22 \%$ & $45 \%$ \\
\hline Medium intensity: & 19 & 12 & 25 & Medium intensity: & 10 & 13 & 18 \\
\hline $45.9 \%$ & $51 \%$ & $38 \%$ & $47 \%$ & $33.6 \%$ & $27 \%$ & $41 \%$ & $34 \%$ \\
\hline High intensity: & 10 & 9 & 15 & High intensity: & 12 & 12 & 11 \\
\hline $27.9 \%$ & $27 \%$ & $28 \%$ & $28 \%$ & $28.7 \%$ & $32 \%$ & $38 \%$ & $21 \%$ \\
\hline
\end{tabular}

Note: How long the entrepreneurs have been doing business: from 1 to 5 years (1-5); from 5 to 10 years (5-10) and more than 10 years $(10+)$. Source: own data collection.

making process [17-18]. However, Hritzuk states that the information is not the most important aspect, but knowledge of transport managers is [19].

In this context, the authors remark that the innovation is too costly and SMEs are too weak in peripheral regions. Therefore, there is a great need for reasonable and flexible institutional support systems [20-22].

\section{Conclusions}

The paper aimed at defining important market risk sources in the transport SME segment. A part of this aim was a comparison of defined market risk sources of transport enterprises based on number of employees, nationality, age, gender, the obtained education and how long the entrepreneurs have been doing business.

The obtained education of entrepreneurs is a statistically significant characteristics to evaluate the market risk sources in selected transport enterprises. The transport managers, which had the university education, evaluated the market risk sources of the higher intensity. The nationality, age, gender and how long the entrepreneurs have been doing business are not statistically significant for evaluation of the market risk sources in the selected transport enterprises.

The authors are aware of the research limits (e. g. a regional character of the study - central European countries and Serbia, the sample size - only 122 transport enterprises of four countries, basic statistical methods as the goodness-of-fit tests). The authors believe that the paper 
has brought several interesting findings and new incentives for further research and discussion regarding the evaluation of the market risks and their sources. The market risk is the most important risk, which negatively influences the business performance of transport enterprises.

It is worth concentrating the future research on a comparison of other risks and their sources: the economic risk, financial risk, operational risk, safety risk, legal risk, human resources risk according to entrepreneurs' characteristics (nationality, age, the obtained education, and so on). Authors believe that the entrepreneurs' attitudes to other risks and their sources are different in the transport segment.

The results of this paper are interesting for small and medium sized enterprises of the transport segment, entrepreneurship support organisations, as well as for the Ministries of Transport in the selected countries. It is important that the managers of transport company's discussion with ministry of transport and others competent institution in the different forms: conference events, education events organized of Ministry of Transport, workshops with topic risk management inside transport companies, and so on. Improving awareness and knowledge of the market risk and its resources is important for the profit of transport companies.

\section{Acknowledgment}

Publication of this paper was supported by: The Scientific Grant Agency - project KEGA No. 030ZU-4/2018 Research of Risk Management in Enterprises in Slovakia to create a new study program Risk Management for the FBI University of Zilina and the Internal Grant Agency No. IGA/FAME2019/001 Key Factors Determining the Business Performance of Small and Medium-Sized Enterprises.

\section{References}

[1] KAMPF, R., LORINCOVA, S., KAPUSTINA, L. M., LIZBETINOVA, L. Motivation level and its comparison between senior managers and blue-collar workers in small and medium-sized transport enterprises. Communications - Scientific Letters of the University of Zilina [online]. 2017, 19(4), p. 43-49. ISSN 1335-4205, eISSN 2585-7878. Available from: http://komunikacie.uniza.sk/index.php/communications/article/view/269

[2] HUDAKOVA, M., MASAR, M., LUSKOVA, M., PATAK, M. R. The dependence of perceived business risks on the size of SMEs. Journal of Competitiveness [online]. 2018, 10(4), p. 54-69. ISSN 1804-171X, eISSN 1804-1728. Available from: https://doi.org/10.7441/joc.2018.04.04

[3] BELAS, J., SOPKOVA, G. Significant determinants of the competitive environment for SMEs in the context of financial and credit risks. Journal of International Studies [online]. 2016, 9(2), p. 139-149. ISSN 2071-8330, eISSN 2306-3483. Available from: https://doi.org/10.14254/2071-8330.2016/9-2/10

[4] CEPEL, M., STASIUKYNAS, A., KOTASKOVA, A., DVORSKY, J. Business environment quality index in the SME segment. Journal of Competitiveness [online]. 2018, 10(2), p. 21-40. ISSN 1804-171X, eISSN 1804-1728. Available from: https://doi.org/10.7441/joc.2018.02.02

[5] ALQUIER, A. M. B., TIGNOL, M. H. L. Risk management in small- and medium-sized enterprises. Production Planning and Control [online]. 2006, 17(3), p. 273-282. ISSN 0953-7287, eISSN 1366-5871. Available from: https://doi.org/10.1080/09537280500285334

[6] AVIlova, T. V., VOYTOlovskiY, N. V., DikAREVA, V. A., CHERnYShEVA, A. M. Efficiency of applying risks management systems at industrial enterprises under market conditions. Journal of Applied Economic Sciences. 2017, 12(3), p. 766-771. ISSN 1843-6110.

[7] KIMBALL, R. C. Failures in risk management. Boston: New England Economic Review, Federal Reserve Bank of Boston, 2000, p. 3-12.

[8] BUGANOVA, K., MORICOVA, V. Innovation of education in risk and crisis management. Turkish Online Journal of Educational Technology. 2017, November Special Issue INTE, p. 177-182. ISSN 1303-6521.

[9] LUSKOVA, M., BUGANOVA, K. Practical problems of university students' learning and performance assessment. Turkish Online Journal of Educational Technology. 2015, p. 436-441. ISSN 1303-6521.

[10] HUDAKOVA, M., SCHONFELD, J., DVORSKY, J., LUSKOVA, M. The market risk analysis and methodology of its more effective management in SMEs in the Slovak republic. Montenegrin Journal of Economics [online]. 2017, 13(2), p. 151-161. ISSN 1800-5845, eISSN 1800-6698. Available from: https://doi.org/10.14254/1800-5845/2017.13-2.10

[11] DVORSKY, J., POPP, J., VIRGLEROVA, Z., KOVACS, S. Assessing the Importance of Market Risk and its Sources in SMEs of the Visegrad Group and Serbia. Advances in Decision Sciences [online]. 2018, 22(A), p. 1-26. ISSN 2090-3359, eISSN 2090-3367. Available from: http://journal.asia.edu.tw/ADS/wp-content/uploads/papers/2018/ ADS-Market-Risk_Final-version.pdf

[12] COSTA, A., FERNANDES, R. Urban public transport in Europe: technology diffusion and market organization. Transportation Research Part A: Policy and Practice [online]. 2012, 46(2), p. 269-284. ISSN 0965-8564, eISSN 1879-2375. Available from: https://doi.org/10.1016/j.tra.2011.09.002 
[13] TUBIS, A. Route risk assessment for road transport companies. In: Contemporary complex systems and their dependability [online]. ZAMOJSKI W., MAZURKIEWICZ J., SUGIER J., WALKOWIAK T., KACPRZYK J. (eds.). Advances in Intelligent Systems and Computing DepCoS-RELCOMEX 2018 : proceedings. Vol 761. Cham : Springer, 2018. ISBN 978-3-319-91445-9, eISBN 978-3-319-91446-6. Available from: https://doi.org/10.1007/978-3-319-91446-6_46

[14] OLIVEIRA CRUZ, C., MIRANDA SARMENTO, J. Institutional "tetris" in infrastructure regulation: harmonizing governance, regulation and policy-making in the transport sector. Case Studies on Transport Policy [online]. 2019, 7(1), p. 22-27. ISSN 2213-624X. Available from: https://doi.org/10.1016/j.cstp.2018.11.003

[15] JARASUNIENE, A., BATARLIENE, N., CIZIUNIENE, K. Business risk management at transport companies: Lithuanian study case. 22nd International Conference Transport Means : proceedings. 2018. ISSN 1822-296X, eISSN 2351-7034, p. 297-304.

[16] LIN, S., CHEN, R., LV, Z., ZHOU, T., JIN, C. Integrated measurement of liquidity risk and market risk of company bonds based on the optimal Copula model. North American Journal of Economics and Finance [online]. 2019, 50, 101004. ISSN 1062-9408. Available from: https://doi.org/10.1016/j.najef.2019.101004

[17] NEDELIAKOVA, E., SEKULOVA, J., NEDELIAK, I. Reduction of transport risks at rail level crossings. 19th International Conference Transport Means : proceedings. 2015. ISSN 1822-296X, eISSN 2351-7034, p. 236-239.

[18] HUDAKOVA, M., DVORSKY, J. Assessing the risks and their sources in dependence on the rate of implementing the risk management process in the SMEs. Equilibrium. Quarterly Journal of Economics and Economic Policy [online]. 2018, 13(3), p. 543-567. ISSN 1689-765X, eISSN 2353-3293. Available from: https://doi.org/10.24136/eq.2018.027

[19] HRITZUK, N. Why companies risk losing customers by not reciprocating on shared data: Rebuilding the datasharing economy in a consumer-driven world. Journal of Advertising Research [online]. 2018, 58(4), p. 394-398. ISSN 0021-8499, eISSN 1740-1909. Available from: https://doi.org/10.2501/JAR-2018-047

[20] LEWANDOWSKA, A., STOPA, M. SMEs innovativeness and institutional support system: the local experiences in qualitative perspective. Polish case study. Oeconomia Copernicana [online]. 2018, 9(2), p. 333-351. ISSN 2083-1277, eISSN 2353-1827. Available from: https://doi.org/10.24136/oc.2018.017

[21] TREShChEVSKY, Y. I., SEREBRYAKOVA, N. A., GOLIKOVA, G. V., VOLKOVA, S. A., VOLKOVA, T. A. The system of state support for small and medium entrepreneurship and evaluation of its effectiveness. Espacios [online]. 2018, 39(12), ISSN 0798-1015. Available from: http://www.revistaespacios.com/a18v39n12/18391212.html

[22] FABUS, M., CSABAY, M. State aid and investment: case of Slovakia. Entrepreneurship and Sustainability Issues [online]. 2018, 6(2), p. 480-488. eISSN 2345-0282. Available from: https://doi.org/10.9770/jesi.2018.6.2(1) 